Volume 11 Nomor 1, November 2019, p. 043 - 061

Faculty of Law, Maranatha Christian University

ISSN: 2085-9945 | e-ISSN: 2579-3520

Nationally Accredited Journal by SINTA

\title{
AMBIGUITAS PENGATURAN KEADAAN BAHAYA DALAM SISTEM KETATANEGARAAN INDONESIA
}

\author{
Agus Adhari \\ Fakultas Sosial Sains, Universitas Pembangunan Panca Budi \\ agusadhari@dosen.pancabudi.ac.id / adharyagus@gmail.com
}

Submitted: 2019-10-06 | Reviewed: 2019-10-31 | Accepted: 2019-11-19

\begin{abstract}
This article aims to analysis state of emergency rules in Indonesia. it contains practical power during state of emergency. A state of emergency is a situation that threaten the life and nation and caused political instability. A state of emergency regulated within article 12 constitution of the republic of Indonesia gives extraordinary power to the President to act against the emergency situation. Besides constitution, state of emergency also regulated by several acts (Perppu 23/1959 UU 24/2007 and UU 7/2012) and each act has different concept of state of emergency. Based on Perppu 23/1959, there are five kinds of situation called state of emergency (rebellion, riot, civil war, disaster and war). Furthermore, UU 24/2007 and UU 7/2012 regulate disaster, riot and civil war separetely and give special authority to the local government (Governor, Bupati and Mayor) proclaiming state of emergency. Besides special authority, these acts ( UU 24/2007 and (UU 7/2012) regulate different concept of how long state of emergency applicable. The result, these different concepts affect several acts such as UU 31/1999 that regulates the death pinalty for those person who doing corruption during state of emergency and local government has no right to proclaim state of emergency based on UU 23/2014 that separates authority between central and local government. State of emergency related to security and defence issues and according to UU 23/2014 security and defence issues are the part of central government authority.
\end{abstract}

Keyword: Constitutional System; Emergency Power; State of emergency.

\section{PENDAHULUAN}

Sejak Indonesia merdeka hingga saat ini, keadaan bahaya di beberapa wilayah Indonesia sering terjadi seperti pemberontakan, perang sipil, bencana alam hingga konflik sosial dengan tingkatan dan skala yang berbeda-beda. Hal ini tidak terlepas dari kondisi geografis, sosial dan politik Indonesia yang sangat rentan melahirkan keadaan bahaya. Kondisi geografis Indonesia yang berada di lempeng tiga benua dan beriklim tropis 
Dialogia luridica: Jurnal Hukum Bisnis dan Investasi

Vol. 11 (1): $043-061$

menjadi faktor terjadinya bencana alam seperti tsunami dan gempa bumi maupun bencana non alam seperti kebakaran hutan. Sedangkan dari kondisi sosial juga sangat berpengaruh di mana Indonesia terdiri dari berbagai suku yang memiliki kultur berbeda sehingga mudah terjadi gesekan horizontal antar suku dalam suatu wilayah. Tidak hanya itu, faktor politik juga sering menjadi faktor lahirnya keadaan bahaya seperti pemberontakan karena ketidakpuasan terhadap kebijakan politik penguasa.

Berdasarkan sejarah, pada beberapa daerah di Indonesia pernah terjadi keadaan bahaya dengan jenis keadaan yang berbeda serta skala besar dan menimbulkan banyak korban jiwa. Beberapa daerah yang dimaksud sebagaimana dalam tabel berikut:

\begin{tabular}{c|ccc}
\multicolumn{1}{c}{ Tahun } & Tempat & Keadaan & Tingkatan Bahaya \\
\hline $1950 a n$ & Jawa & Keadaan Perang & Keadaan Perang \\
& Timur & & \\
1999 & Timor & Pemberontakan & Darurat Militer \\
& Timur & & \\
2000 & Maluku & Konflik & Darurat Sipil \\
2001 & Sampit & Konflik & Tidak Ada \\
2002 & Aceh & Konflik & Darurat Sipil \\
2003 & Aceh & Pemberontakan & Darurat Militer \\
2004 & Aceh-Nias & Bencana Alam & Tidak Ada \\
2018 & Lombok & Bancana Alam & Tidak Ada \\
2018 & Palu- & Bencana Alama & Tidak Ada \\
& Donggala & & Tidak Ada
\end{tabular}

Sumber: Diolah dari beberapa data yang dijelaskan selanjutnya.

Peristiwa terkini yang belum lama terjadi adalah gempa di Lombok, gempa bumi dan tsunami di Palu dan Donggala yang terjadi pada tahun 2018, kemudian konflik di Wamena yang terjadi pada tahun 2019. Dari beberapa peristiwa yang terjadi, dapat disimpulkan jika dilihat dari ancamannya, peristiwa tersebut merupakan bagian dari keadaan bahaya. Hal ini diatur secara khusus dalam Pasal 12 UUD 1945 yang menyatakan 
Vol. 11 (1): $043-061$

"Presiden menyatakan keadaan bahaya, syarat-syarat dan akibat keadaan bahaya diatur dengan undang-undang" dan undang-undang yang dimaksud adalah Perppu Nomor 23 Tahun 1959 tentang Keadaan Bahaya. ${ }^{1}$

Perppu 23/1959 mengatur keadaan bahaya dalam tiga tingkatan yaitu keadaan darurat sipil, keadaan darurat militer dan keadaan perang. Dalam Penjelasan Pasal 1 Perppu 23/1959 dapat disimpulkan lima kondisi yang nantinya menjadi bagian dari tingkatan keadaan bahaya. Lima kondisi tersebut adalah: pemberontakan (kerusuhan bersenjata), kerusuhan, perang saudara, bencana alam dan perang. Pembagian kelima kondisi keadaan bahaya tersebut dibagi menjadi tiga bagian, yaitu: perang saudara, kerusuhan dan bencana alam termasuk kategori keadaan darurat sipil, keadaan pemberontakan (bersenjata) masuk dalam kategori keadaan darurat militer sedangkan perang masuk dalam kategori keadaan perang.

Perppu 23/1959 tidak secara jelas mendefisikan kelima kondisi tersebut, karena penafsiran suatu keadaan bahaya dalam Perppu 23/1959 menjadi subjektifitas Presiden yang ditafsirkan sebagai kewenangan khusus berdasarkan Pasal 12 UUD 1945. Perppu 23/1959 hanya menyebut lima kondisi dan pengkategoriannya dalam tingkatan keadaan bahaya. Dalam praktiknya, ketentuan dalam Perppu 23/1959 diberlakukan dalam kondisi perang sipil dan pemberontakan seperti yang terjadi di Timor Timur (Timor Leste), Maluku dan Aceh.

Di Indonesia, keadaan bahaya dalam tingkatan keadaan perang pernah diterapkan pada Tahun 1950an pada pasa kekuasaan orde lama yang diberlakukan melalui Keputusan Presiden 225 Tahun 1957 yang kemudian disahkan melalui UU 79 Tahun 1957 yang kemudian diubah dengan Perppu 23/1959. Kemudian dalam tingkatan darurat sipil dan militer juga pernah ditetapkan di Timor Timur (darurat militer 1999), Maluku (darurat sipil 2000-2002) dan Aceh (darurat sipil 2002, darurat militer 2003).

Pada tahun 1999 saat transisi pemerintahan orde baru ke era reformasi, di mana Timor Timur sedang melakukan pemungutan suara konsekuensi referendum, Jendral TNI Wiranto mengusulkan kepada Presiden Habibie untuk mentapkan statu darurat militer menanggapi kerusuhan yang terjadi selama referendum. Walaupun kabinet Indonesia

\footnotetext{
${ }^{1}$ Disebut undang-undang pelaksana dari Pasal 12 UUD 1945, karena hanya Perppu 23/1959 yang secara langsung merujuk Pasal 12 UUD 1945 sebagai konsideran lahirnya Perppu tersebut. Bandingkan dengan UU 24/2007 tentang Bencana Nasional dan UU 7/2012 tentang Konflik Sosial yang tidak menyebutkan Pasal 12 UUD 1945 sebagai dasar lahirnya peraturan tersebut.
} 
Dialogia luridica: Jurnal Hukum Bisnis dan Investasi

Vol. 11 (1): $043-061$

menolak menetapan darurat militer yang diusulkan oleh Jendral TNI Wiranto pada tanggal 6 September 1999, namun setelah bertemu empat mata keesokan harinya. Presiden BJ. Habibie mengeluarkan Keppres Nomor 107 Tahun 1999 tentang penetapan darurat militer di Timor-Timur yang dipimpin oleh Mayor Jendral Kiki Syahnakri. ${ }^{2}$

Kemudian darurat sipil dalam upaya mengatasi kerusuhan dilakukan di Maluku dan Maluku Utara melalui Keputusan Presiden Nomor 88 Tahun 2000 tentang Keadaan Darurat Sipil di Provinsi Maluku dan Provinsi Maluku Utara sebagaimana telah diubah dengan Keputusan Presiden Nomor 40 Tahun 2002. Kerusuhan yang terjadi di Maluku dan Maluku Utara merupakan kerusuhan horizontal. Kemudian di Aceh, darurat militer ditetapkan melalui Keppres Nomor 28 Tahun 2003, hal dilakukan setelah pemerintah menaikan status dari darurat sipil menjadi darurat militer. Keputusan ini diambil setelah menemui jalan buntu pada pertemun antara GAM dan TNI di Tokyo. Karena tidak ada yang mengalah pada pertemuan itu di mana GAM bersikeras tidak mau melucuti senjata dan TNI tidak mau keluar dari aceh, maka pada tanggal 19 Mei 2003 Presiden Megawati Soekarno Putri menetapkan darurat militer di Aceh. ${ }^{3}$

Sementara untuk jenis bencana alam, Indonesia tidak pernah menetapkan status bencana atau konflik sosial. Kendati peraturan tersebut sudah berlaku. Pada bencana Tsunami Aceh yang terjadi pada tanggal 26 Desember 2004 tidak pernah ditetapkan sebagai dasar penerapan darurat sipil. Hal ini dapat dilihat dalam Keppres Nomor 43 tahun 2004 tentang Perubahan status darurat militer menjadi darurat sipil di Provinsi Aceh tertanngal 18 Mei 2004 yang berlaku selama 6 bulan hingga November 2004. Bencana tsunami di Aceh justru ditetapkan sebagai bencana nasional melalui Keppres Nomor 112 Tahun $2004^{4}$

Pada tahun 2007, lahir UU 24/2007 tentang Bencana Nasional yang ditafsirkan memiliki dua tujuan; Pertama, sebagai aturan khusus untuk melepaskan status bencana alam dari bagian keadaan bahaya; Kedua, sebagai aturan spesialis untuk mengatasi bencana nasional. Lahirnya UU tersebut tidak terlepas dari peristiwa Tsunami di Aceh yang terjadi tahun 2004. Namun pada beberapa peristiwa bencana alam yang terjadi

\footnotetext{
${ }^{2}$ Chris Manning, Peter Van Dierman, Indonesia di Tengah Transisi: Aspek-Apek Sosial Reformasi Dan Krisis, Yogyakarta: LkiS, 2000, hlm. 127.

${ }^{3}$ Harry Kawilarang, Aceh Dari Sultan Iskandar Muda Ke Helsinki. Banda Aceh: Bandar Publishing, 2008, hlm. 166.

${ }^{4}$ Hasjim Djalal, Dini Sari Djalal, Seeking Lasting Peace in Aceh, Jakarta: Centre for Strategic and International Studies, 2006, hlm. 168.
} 
Vol. $11(1): 043-061$

belakangan ini seperti Gempa dan Tsunami di Palu dan Donggala tidak juga ditetapkan status bencana nasional atau bencana daerah, meskipun jumlah korban mencapai ribuan. ${ }^{5}$

Pada tahun 2012, kembali lahir UU 7/2012 tentang Konflik Sosial, UU tersebut memiliki tujuan yang hampir sama dengan UU 24/2007. Fokusnya adalah mengatur secara khusus mengenai konflik sosial yang terjadi di masyarakat. Hal ini wajar jika melihat beberapa peristiwa konflik sosial yang pernah terjadi di Indonesia akibat gesekan horizontal seperti pada tragedi Sampit dan Ambon. Namun, sampai sekarang, UU 7/2012 yang mengatur status konflik sosial tidak pernah pula diterapkan, termasuk pada peritiwa yang terjadi di Wamena yang menelan korban sebanyak 31 korban jiwa dan jumlah pengungsi lebih dari sepuluh ribu jiwa. ${ }^{6}$

Kendati tiga peraturan telah mengatur mengenai kondisi-kondisi tersebut, namun tidak satupun dilaksanakan. Hal ini dapat dianalisis melalui presfektif politik hukum, di mana aturan mengenai keadaan bahaya sulit dilaksanakan karena tidak jelasnya konsep awal pengaturan keadaan bahaya, sehingga dalam taraf praktik justru konfigurasi politik lebih dominan daripada pelaksanaan aturan itu sendiri. Pada bagian pembahasan akan diuraikan mengenai aspek konseptual keadaan bahaya sebagai pemahaman untuk melihat bagaimana praktik aturan keadaan bahaya harusnya dilaksanakan.

\section{PEMBAHASAN}

\section{Keadaan Bahaya Persfektif Ilmiah}

Keadaan bahaya secara teoretis dipahami sebagai keadaan yang dapat mengancam stabilitas negara meliputi stabilitas sosial, ekonomi, pertahanan dan keamanan. Keadaan bahaya merupakan syarat utama untuk memberlakukan hukum tata negara darurat. Antara keadaan bahaya dan hukum tata negara darurat memiliki korelasi yang tidak terputus. Keadaan bahaya disebut juga faktor penyebab hukum tata negara darurat diberlakukan. ${ }^{7}$

\footnotetext{
${ }^{5}$ Berdasarkan laporan Kompas tanggal 7 Oktober 2018 dengan judul "Hingga Minggu, Jumlah Korban Tewas Gempa dan Tsunami di Sulteng 1.763 Orang” diperkirakan jumlah korban meninggal akibat gempa dan tsunami lebih dari seribu jiwa. Diakses di www.nasional.kompas.com pada tanggal 9 September 2019. ${ }^{6}$ Berdasarkan data Kepolisian Resor Jayawijaya sebagaimana diliput Kompas tanggal 26 September 2019, jumlah korban jiwa mencapai 31 orang. Diakses melalui laman www.regional.kompas.com dengan judul "Data Polisi, Korban Tewas akibat Kerusuhan di Wamena Berjumlah 31" pada 5 Oktober 2019. Sedangkan untuk jumlah pengungsi berdasarkan data Lanud Silas Pare-Pare yang dikutip Harian Tempo 5 Oktober 2019 menyatakan jumlah pengungsi lebih dari sepuluh ribu jiwa. Diakses di www.nasional.tempo.com dengan judul “Jumlah Pengungsi Kerusuhan Wamena Lebih 10 Ribu Orang” pada tanggal 5 Oktober 2019. ${ }^{7}$ Herman Sihombing mendefinisikan keadaan bahaya sebagai bagian dari Hukum Tata Negara Darurat Subjektif yang sifatnya tidak tertulis dan penggunaannya merupakan ranah kekuasaan eksekutif. Sedangkan Hukum Tata Negara Darurat Objektif merupakan aturan tertulis yang digunakan untuk mengatasi keadaan
} 
Dialogia luridica: Jurnal Hukum Bisnis dan Investasi

Vol. 11 (1): $043-061$

Praktik ketatanegaraan, keadaan suatu negara dibagi menjadi dua, yaitu negara dalam keadaan normal (ordinary condition) dan negara dalam keadaan tidak normal (extraordinary condition) atau darurat (emergency condition). Keadaan bahaya (state of emergency) menurut Jimly Asshiddiqie adalah keadaan yang tiba-tiba mengancam ketertiban umum, yang menuntut negara untuk bertindak secara dengan cara tidak lazim menurut aturan yang berlaku dalam keadaan normal. Sementara menurut Herman Sihombing ${ }^{1}$, keadaan bahaya adalah serangkaian pranata dan wewenang negara secara luar biasa dan istimewa, untuk dalam waktu yang sesingkat-singkatnya dapat menghapuskan bahaya yang mengancam dan mengembalikannya ke dalam kehidupan biasa menurut perundang-undangan dan hukum yang umum dan biasa. ${ }^{8}$

Dalam pengertian yang praktis, istilah yang dipakai dalam UUD 1945 ada dua yaitu keadaan bahaya dan keadaan perang (Pasal 11 UUD 1945). Keduanya menunjuk kepada persoalan yang sama, yaitu keadaan yang dikecualikan dari keadaan yang bersifat normal. ${ }^{9}$ Sementara terkait hal ihwal kegentingan yang memaksa sebagaimana diatur dalam Pasal 22 ayat 1 UUD 1945 menurut Mahakamh Konstitusi tidak selalu berkaitan dengan keadaan bahaya sebagaimana dalam putusan Nomor 003/PUU-III/2005 yang menfasirkan prasa "hal ihwal kegentingan yang memaksa" tidak selalu terkait dengan keadaan bahaya. ${ }^{10}$

Konsep keadaan bahaya berakar pada sejarah romawi yang menerapkan konsep "diktator" dalam keadaan bahaya atau di luar kendali yang diakibatkan oleh serangan eksternal atau pemberontakan internal. Hal ini kemudian berkembang mulai abad 18 hingga abad 19 di mana banyak konstitusi-konstitusi di Eropa mulai mengelaborasi gagasan keadaan bahaya dalam konstitusinya, atau dalam undang-undang khusus yang terpisah. Sejarah keadaan bahaya sebagai konsep hukum (legal concept) di era modern berasal dari Eropa Barat pada abad ke sembilan belas. Keadaan bahaya dibangun atas

darurat tersebut. Lihat Herman Sihombing, Hukum Tata Negara Darurat, Jakarta: Djambatan, 1996, hlm. 28.

${ }^{8}$ Dengan demikian unsur yang harus ada dalam hukum tata negara adalah: 1 . Adanya bahaya negara yang patut dihadapi dengan upaya luar biasa; 2 . Upaya biasa, pranata yang umum dan lazim tidak memadai untuk digunakan menganggapi dan menanggulangi bahaya yang ada; 3 . Kewenangan luar biasa yang diberikan dengan hukum kepada pemerintah negara untuk secepatnya mengakhiri bahaya darurat tersebut, kembali ke dalam keadaan atau kehidupan normal; 4 . Wewenang luar biasa dari hukum tata negara darurat itu adalah untuk sementara waktu saja, sampai keadaan darurat itu di pandang tidak membahayakan lagi.

${ }^{9}$ Jimly Asshiddiqie, Op.,Cit, hlm. 213.

${ }^{10}$ Fitra Arsil, "Menggagas Pembatasan Pembentukan dan Materi Muatan Perppu: Studi Perbandingan Pengaturan dan Penggunaan perppu di Negara-Negara Presidensial", Jurnal Hukum \& Pembangunan, Volume 48. No. 1, 2018, hlm. 1-21. 
Dialogia luridica: Jurnal Hukum Bisnis dan Investasi

Vol. 11 (1): $043-061$

dasar dikotomi buatan antara norma (norm) dan pengecualian (exception) dalam hukum. Hal ini bertujuan untuk menciptakan keseimbangan atas kepentingan tujuan sosial serta hak asasi manusia. Keadaan bahaya dapat dijadikan legitimasi pembatasan hak yang lebih besar oleh pemerintah. ${ }^{11}$

Pengelaborasian keadaan bahaya dalam suatu rezim hukum (legal regime) mulai diberlakukan pada masa Revolusi Prancis dan diterapkan dalam sistem hukum nasional di Prancis pada pertengah abad ke 20. Secara umum, keadaan bahaya di Prancis berkaitan dengan "tindakan pemerintah yang dilakukan selama krisis nasional yang besar. ${ }^{12} \mathrm{Hal}$ ini dibuktikan, setelah Revolusi Prancis pada Tahun 1848 Konstitusi Republik Kedua Prancis memasukan pasal baru yang menjelaskan perihal kejadian, bentuk dan akibat keadaan bahaya (state of siege) dielabolasi dalam hukum. ${ }^{13}$

Kemudian pada abad yang sama, konsep keadaan bahaya mulai relevan diterapkan di Amerika Utara, khususnya dalam praktik ketatanegaraan Amerika Serikat. Selama perang sipil, Presiden Lincoln menghentikan (suspended) writ of habeas corpus yang dijamin dalam Pasal 1 Konstitusi Amerika di mana hal ini dianggap biasa. Lincoln juga melakukan sensor pada surat-surat dan memberikan otoritas untuk melakukan penangkapan terhadap tersangka yang tidak loyal dan berhianat. Dalam pidatonya di hadapan Kongres pada Tahun 1861 saat peperangan dimulai, Lincoln menegaskan tindakannya dengan mendeklarasikan "whether strictly legal or not, were ventured upon, under what appeared to be a popular demand, and a public necessity". ${ }^{14}$

Secara umum, terdapat dua pandangan terhadap keadaan bahaya. Pada tatanan teoritis, ada pandangan yang mendukung pendekatan negara hukum (rule of law approach) di mana keadaan bahaya harus tunduk pada konstitusi atau undang-undang, dan pandangan yang mengkritik pengaturan keadaan bahaya dalam hukum (state of emergency/exception cannot be reduced to legal norms) yang kemudian dipahami bahwa keadaan bahaya merupakan bagian dari extrajudicial atau sebagai sesuatu yang lebih

\footnotetext{
11 Scott P. Sheeran, "Reconceptualizing States of Emergency under International Human Rights Law: Theory, Legal Doctrine, and Politics", Michigan Journal of International Law, Volume 34, Issue 3, 2013, hlm. 491-557.

12 Claudio Grossman. "A Framework for the Examination of States of Emergency Under the American Convention on Human Rights." American University International Law Review Volume 1, No. 1, 1986, hlm. 35-55.

${ }^{13}$ Scott P. Sheeran, Op., Cit, hlm. 496.

14 Frank J. Williams, "A Popular Demand, and a Public Necessity": Lincoln and Civil Liberties. OAH Magazine of History, Volume 21, Issue 1, 2007, hlm. 24-27.
} 
Dialogia luridica: Jurnal Hukum Bisnis dan Investasi

Vol. $11(1): 043-061$

tinggi dari hukum kedudukannya. ${ }^{15}$ Pendukung padangan ini mengedepankan pendekatan kedaulatan negara (sovereignty approach) yang berpendapat bahwa tidak mungkin untuk mengontrol tindakan eksekutif dalam keadaan bahaya menggunakan mekanisme hukum yang standar. Dalam hal ini Schmitt menyatakan:

"The precise details of an emergency cannot be anticipated, nor can one spell out what may take place in such a case, especially when it is truly a matter of an extreme emergency and of how it is to be eliminated. The precondition as well as the content of jurisdictional competence in such a case must necessarily be unlimited. From the liberal constitutional point of view, there would be no jurisdictional competence at all. The most guidance the constitution can provide is to indicate who can act in such a case". ${ }^{16}$

Pernyataan Schmitt banyak digunakan dan didukung oleh banyak penulis yang mengkaji masalah Tragedi 11 September di Amerika Serikat dalam kaitannya dengan perdebatan kewenangan Presiden dalam menyikapi keadaan bahaya yang diatur dalam Konstitusi Amerika Serikat. Namun tidak dengan Georgio Agamben seorang pakar state of exception yang menolak pendapat Schmitt. Agamben menyebut state of exception sebagai "a fictio iuris par excellence" yang berarti hukum harus ditegakkan dalam kondisi kritis sekalipun sebagai bagian dari tegaknya hukum. ${ }^{17}$ Hal paling penting untuk dipahami, bahwa pemberlakukan keadaan bahaya berkaitan dengan kondisi suatu negara, apakah itu demokratis atau tidak demokratis. Dalam hal ini Agamben berpendapat "It is important not to forget that the modern state of exception is a creation of the democraticrevolutionary tradition and not the absolutist one". ${ }^{18}$

Berdasarkan paparan di atas, terdapat dua pandangan yang masing-masing mengemukakan teori pembenar atas tindakan yang dilakukan selama keadaan bahaya berlangsung. Penulis dalam hal ini berpegang pada teori bahwa keadaan bahaya itu tidak dapat menghilangkan kedudukan hukum, sebagaimana yang dikemukakan oleh Georgio Agamben di atas. Dengan demikian hukum dalam hal ini, baik berbentuk konstitusi ataupun undang-undang memiliki legitimasi keberlakuan selama keadaan bahaya terjadi, sehingga Presiden sebagai penyelenggara kekuasaan darurat tetap memiliki hubungan

\footnotetext{
15 Stephen Humphreys, "Legalizing Lawlessness: On Giorgio Agamben's State of Exception”, The European Journal of International Law, Volume 17 No. 3, 2006, hlm. 677-687.

${ }^{16}$ Carl Schmitt, Political Theology: Four Chapters on Theory of Sovereignty, Terjemahan George Schwab, Chicago: University of Chicago Press, 2005, hlm. 6-7.

${ }^{17}$ Georgio Agamben, The Omnibus Homo Sacer, Stanford: Standford University Press, 2017, hlm. 217.

${ }^{18}$ Giorgio Agamben, State of Exception, Chicago: The University of Chicago Press, 2005, hlm. 5
} 
Dialogia luridica: Jurnal Hukum Bisnis dan Investasi

Vol. $11(1): 043-061$

dengan cabang kekuasaan lainnya sebagaimana diatur dalam konstitusi atau undangundang.

Berbagai literatur mencatat keadaan bahaya selalu identik dengan perang dan teroris (war and terrorism), hanya sedikit penulis yang mengaitkan keadaan di luar perang dan teroris sebagai keadaan bahaya. Indonesia justru sebaliknya, menjadikan terorisme bukan menjadi bagian dari keadaan bahaya karena dalam Undang-Undang Nomor 15 tahun 2003 serta perubahannya melalui Undang-Undang Nomor 5 Tahun 2018 tidak ada penggolongan terorisme sebagai bagian dari keadaan bahaya kendati terdapat prasa "teror" dalam UU 24/2007 yang mengkategorikan "teror" sebagai bagian dari bencana sosial.

Merujuk pada pendapat John Armitage yang berpendapat jika keadaan bahaya merupakan keadaan tertentu yang tidak dapat diklasifikasikan jenisnya. Adapun indikasi dari keadaan bahaya adalah ancaman yang datang baik dari dalam maupun dari luar. Aturan mengenai indikasi keadaan bahaya harus dilakukan secara umum mengingat saat ini keadaan bahaya yang dapat mengancam keamanan dan pertahanan negara tidak terbatas pada faktor klasik seperti kerusuhan dan bencana, melainkan krisis ekonomi juga menjadi bagian yang dapat mengancam keamanan dan pertahanan negara. Terkait pentingnya indikasi ancaman dalam keadaan bahaya disebutkan jelas dalam Pasal 4 (1) International Covenant on Civil and Political Rights (ICCPR):

"In time of public emergency which threatens the life of the nation and the existence of which is officially proclaimed, the States Parties to the present Covenant may take measures derogating from their obligations under the present Covenant to the extent strictly required by the exigencies of the situation, provided that such measures are not inconsistent with their other obligations under international law and do not involve discrimination solely on the ground of race, colour, sex, language, religion or social origin."

ICCPR menyebutkan dalam keadaan bahaya (public emergency) terdapat ancaman yang mengancamhidup dan eksistensi negara. Dengan demikian, kadaan bahaya selalu berkaitan dengan ancaman. Hal yang sama juga terdapat dalam BAB II Pasal 39-41 Siracusa Principles on the Limitation and Derogation of Provisions in the International Covenant on Civil and Political Rights yang menyatakan jika keadaan bahaya selalu berkaitan dengan ancaman, sebagaimana berikut:

39. "A state party may take measures derogating from its obligations under the International Covenant on Civil and Political Rights pursuant to Article 4 (hereinafter called "derogation measures") only when faced with a situation of 
Vol. 11 (1): $043-061$

exceptional and actual or imminent danger which threatens the life of the nation. A threat to the life of the nation is one that:(a) affects the whole of the population and either the whole or part of the territory of the State,and(b) threatens the physical integrity of the population, the political independence or the territorial integrity of the State or the existence or basic functioning of institutions indispensable to ensureand project the rights recognized in the Covenant. 40. Internal conflict and unrest that do not constitute a grave and imminent threat to the life ofthe nation cannot justify derogations under Article 4. 41. Economic difficulties per se cannot justify derogation measures."

Keadaan bahaya diklasifikasikan pada jenis-jenis keadaan yang dapat mengancam manusia atau negara. Jenis-jenis tersebut meliputi; peperangan baik internal (internal armed conflict) seperti pemberontakan bersenjata oleh kelompok yang mengancam keamanan dan pertahanan negara. Kemudian perang yang berskala internasional (international armed conflict) atau perang yang terjadi antar negara dan jenis perang ini tunduk pada ketentuan Konvensi Genewa 1949. ${ }^{19}$ Selain perang keadaan bahaya juga berkaitan dengan bencana alam maupun wabah penyakit yang terjadi tiba-tiba di luar prediksi atau bukan disebabkan oleh manusia (human error). Terorisme juga menjadi salah satu jenis keadaan yang berkaitan dengan keadaan bahaya karena sifatnya mengancam keamanan dan pertahanan negara. Kemudian jenis keadaan lain yang berkaitan dengan keadaan bahaya adalah krisis keuangan atau krisis ekonomi yang terjadi dalam suatu negara. Jenis-jenis tersebut merupakan kondisi dasar suatu negara dapat berada dalam keadaan bahaya.

Dari jenis-jenis keadaan bahaya tersebut kemudian lahir satu sifat yaitu ancaman baik bagi manusia maupun negara. Sifat mengancam tersebut merupakan sifat yang tidak dapat diprediksi terjadinya sehingga dapat disebut ancaman tiba-tiba (sudden attack). Karena sifatnya yang tiba-tiba maka metode penanggulangannya perlu diatur secara khusus. Hal ini kemudian melahirkan konsep hukum tata negara darurat atau sistem penyelenggaraan negara yang khusus terjadi saat negara dalam keadaan bahaya. Sistem ini memisahkan penyelenggaraan negara dalam keadaan normal.

\footnotetext{
19 Konvensi Genewa 1949 secara khusus mengatur mengenal konflik bersenjata baik yang berskala internasional melalui Pasal 2 Konvensi Genewa dan berskala internal dalam suatu negara melalui Pasal 3 Konvensi Genewa. Pada pelaksanaan ketentuan pasal 2 dan 3 Konvensi tersebut diatur lebih lanjut teknisnya dalam "Protocol I (1977) relating to the Protection of Victims of International Armed Conflicts" dan "Protocol II (1977) relating to the Protection of Victims of Non-International Armed Conflicts". Indonesia sendiri telah mengadopsi Konsvensi Genewa melalui Undang-Undang Nomor 59 tahun 1958 tentang Ikut Serta Negara Republik Indonesia Dalam Seluruh Konpensi Jenewa Tanggal 12 Agustus 1949.
} 
Dialogia luridica: Jurnal Hukum Bisnis dan Investasi

Vol. $11(1): 043-061$

\section{Kekuasaan dalam Keadaan Bahaya Persfektif Hukum Tata Negara}

Setelah mengulas mengenai konsep keadaan bahaya, selanjutnya akan diulas mengenai kekuasaan dalam keadaan bahaya. Dua hal ini merupakan bagian yang tidak terpisahkan, di mana keadaan bahaya sebagai objek yang harus ditanggulangi oleh kekuasaan sebagai subjeknya. Praktik kekuasaan selama keadaan bahaya berbeda dengan praktik kekuasaan dalam keadaan normal. Louis Fisher sebagaimana dikutip Edelson berpendapat bahwa kekuasaan dalam keadaan bahaya adalah tindakan yang bertujuan untuk menanggulangi ancaman tiba-tiba yang mengancam negara, selengkapnya sebagaimana berikut:

"emergency presidential power as simply the power to take actions necessary to resist sudden attacks either againts the mainland........". Kemudian Fisher juga menyimpulkan "that president possesses limited implied emergency power to act unilaterally in order to defend the nation; however, the president must seek retroactive approval from congress, which may either vindicate or censure the president's actions". ${ }^{20}$

Kemudian Anna Khakee mendefinisikan kekuasaan dalam keadaan bahaya sebagai kekuasaan prerogatif Presiden untuk bertindak secara khusus mengatasi keadaan bahaya, selengkapnya sebagaimana berikut:

"emergency powers are those special prerogatives that a government or a president can resort to in extraordinary situations such as war, insurgency, terrorist attacks, or other severe threats to the state, environmental calamities, serious industrial accidents, pandemics or similar situations that threaten a great number of lives". ${ }^{21}$

Dari dua pendapat di atas, dapat disimpulkan jika kekuasaan dalam keadaan bahaya merupakan kewenangan Presiden atau eksekutif dalam suatu negara yang bertindak secara khusus untuk mengatasi keadaan bahaya yang mengancam. Kemudian terdapat perdebatan mengenai sepanjang mana kekuasaan dalam keadaan bahaya tersebut dapat dilaksanakan dan bagaimana bentuk pengawasannya. Hal ini tentu perlu dianalisis, karena kekuasaan dalam keadaan bahaya dapat bersifat permanen dan mengakibatkan kerusakan sistem bahkan dapat mengubah hukum dasar (konstitusi) jika tidak memiliki mekanisme pengawasan yang baik. Sebagaimana terjadi dalam Konstitusi Weimar yang menjadi

\footnotetext{
${ }^{20}$ Chris Edelson, Emergency Presidential Power: From The Drafting of Constitution to the War on Terror, Wisconsin: The University of Wisconsin Press, 2013, hlm. 8.

21 Anna Khakee, "Securing Democracy? A Comparative Analysis of Emergency Powers in Europe". “Geneva Centre for the Democratic Control of Armed Forces (DCAF)" Policy Paper No. 30, 2009, hlm. $1-32$.
} 
Dialogia luridica: Jurnal Hukum Bisnis dan Investasi

Vol. 11 (1): $043-061$

dasar legalnya kekuasaan fasisme Hitler atas nama keadaan bahaya dalam konstitusi tersebut. $^{22}$

Presiden dalam keadaan bahaya dapat bertindak secara khusus bahkan mereduksi keberlakuan aturan yang dianggap menghalangi proses pemulihan keadaan bahaya. Dengan dideklarasikannya keadaan bahaya, maka presiden dapat bertindak secara khusus tanpa perlu terikat pada ketentuan-ketentuan yang bersifat administratif lazimnya berlaku dalam keadaan normal. Tentu, kekuasaan yang diberikan tersebut tidak dengan sendirinya bersifat permanen, harus ada mekanisme pengawasan yang dapat menghentikan kekuasaan tersebut jika dianggap tidak relevan lagi dilaksanakan. Dengan demikian lahir permasalahan terkait siapa yang berwenang untuk mengentikan kekuasaan. Sebagaimana pendapat Anna Khakee yang menjelaskan bahwa terdapat dya masalah dalam opraktik kekuasaan dalam keadaan bahaya meliputi stabilitas cabang kekuasaan dan jaminan HAM, sebagaiamana berikut:

Reality is more complex, however, and as already mentioned, two aspects of emergency rule in particular are often problematic: (1) safeguarding the balance of powers, i.e. the powers of parliament and the judiciary vis-à-vis the executive, and (2) protecting human rights and the rule of law. ${ }^{23}$

Sebagaimana dipahami, kekuasaan dalam keadaan bahaya memiliki batasan secara legal yang diatur dalam peraturan khusus, sedangkan jika tidak diatur batasannya, harus terdapat mekanisme pengawasan yang dilakukan oleh parlemen atau pengawasan judicial sebagai bagian dari pengawasan khusus dalam keadaan bahaya. Jika dilihat, keadaan bahaya yang terjadi tidak pernah sampai mengakibatkan lumpuhnya pemerintahan dan bahkan parlemen, oleh sebab itu sangat wajar parlemen diberikan kewenangan untuk mengawasi jalannya kekuasaan dalam keadaan bahaya.

Terdapat dua konsep pengawasan kekuasaan dalam keadaan bahaya; Pertama melalui "retroactive congress approval" sebagaimana pendapat Louis Fisher di mana Presiden dapat terlebih dahulu menjalankan kekuasaan dalam keadaan bahaya dan setelah memungkinkan dapat meminta persetujuan kongres (parlemen) untuk memberikan legitimasi kekuasaan khusus tersebut. Mekanisme pengawasan ini dapat memberikan kemudahan pada presiden untuk bertindak cepat menanggulangi keadaan bahaya saat

${ }^{22}$ Panikos Panayi (ed), Weimar and Nazi Germany: Continuities and Discontinuities, New York: Routledge, 2014, hlm. 258.

${ }^{23}$ Anna Khakee, Loc., Cit 
Dialogia luridica: Jurnal Hukum Bisnis dan Investasi

Vol. $11(1): 043-061$

parlemen tidak bersidang atau dalam masa reses. Konsep ini juga hampir mirip dengan konsep "The Supermajoritarian Escalator" yang digagas Bruce Ackermann, di mana presiden diberikan kekuasaan untuk bertindak secara unilateral dalam waktu tertentu (short-run responses), dan atau selama legislatif belum memberikan keputusan dan pertimbangan. Namun saat legislatif telah memiliki keputusan, sekitar 1 minggu atau dua minggu maksimal kekuasaan dalam keadaan bahaya harus diakhiri kecuali kekuasaan tersebut mendapatkan persetujuan mayoritas (majority approval). ${ }^{24}$ Kedua mekanisme tersebut sebenarnya sudah diterapkan di Indonesia terkait pembentukan perppu sebagaimana diatur dalam Pasal 22 UUD 1945 di mana Presiden dapat menetapkan perppu dalam hal kegentingan yang memaksa yang selanjutnya Perppu tersebut dibuatkan RUU dan diajukan pada DPR untuk diterima atau ditolak.

Kedua, konsep "judiciary control" di mana lembaga peradilan dapat memberikan keputusan terhadap kekuasaan khusus presiden dalam keadaan bahaya. Konsepnya adalah individu atau kelompok yang merasa dirugikan oleh kekuasaan dalam keadaan bahaya tersebut dapat menguji keabsahan kekuasaan yang dirasa tidak lagi relevan dengan keadaan bahaya. Intinya, individu atau kelompok yang merasa keadaan bahaya telah berakhir, namun kekuasaan khusus presiden tetap berlanjut. Hal ini dapat saja terjadi pada negara yang tidak jelas mengatur batasan waktu kekuasaan darurat atau negara yang tidak jelas mengatur peran legislatif dalam keadaan bahaya, sehingga konsep "judiciary control" dapat digunakan. Penggunaan konsep ini didasarkan pada konsep pemberian kekuasaan khusus tersebut. Lazimnya, Presiden mendapatkan kekuasaan khusus dari konstitusi atau undang-undang, dan jika konstitusi dan undang-undang tidak mengatur batasannya, maka secara ex officio lembaga peradilan dapat menggunakan kekuasaannya sepanjang ada pihak yang merasa dirugikan. Konsep ini pernah dilaksanakan di Amerika Serikat pada kasus Youngstown Sheet and Tube Co. v. Sawyer (343 U.S. 579, 1952). ${ }^{25}$ Mahkamah Agung Amerika Serikat dalam putusan mayoritas menyatakan "that the President had no power to act except in those cases expressly or implicitly authorized by

\footnotetext{
${ }^{24}$ Bruce Ackerman, "The Emergency Constitution", Makalah dipresentasikan di The Cardozo Conference on Emergency Powers and Constitutions and the Yale Global Constitutuonalisme Seminar, 2004, hlm. 1029-1091.

${ }^{25}$ Dalam kasus tersebut, Presiden Amerika Serikat Henry Truman memiliterisasi sebuah perusahaan yang dimiliki oleh swasta dengan alasan keadaan darurat dan deklarasi keadaan darurat dilakukan tanpa persetujuan kongres. Lihat Christopher Schroeder et al, Pesidential Power Stories, New York: Thomson Reuters/Foundation Press, 2009, hlm. 244-245.
} 
Dialogia luridica: Jurnal Hukum Bisnis dan Investasi

Vol. 11 (1): $043-061$

the Constitution or an act of Congress. ${ }^{26}$ Amerika Serikat pada waktu itu belum mengatur secara khusus mengenai keadaan bahaya dan kekuasaannya, sehingga kekuasaan dalam keadaan bahaya ditafsirkan sebagai kewenangan residu Presiden karena tidak diatur dan pelaksanaan kekuasaan tersebut merupakan kekuasaan khusus Presiden yang lahir dari tafsir prasa "commander in chief". Baru pada tahun 1976, Amerika Serikat mengatur secara khusus mengenai keadaan bahaya dan kekuasaannya dalam National Emegency Act $1976 .^{27}$

\section{Ambigutas Keadaan Bahaya dalam Perundangan Indonesia}

Keadaan bahaya di Indonesia tidak memiliki konsep yang baku, ketentuan mengenai keadaan bahaya diatur dalam tiga peraturan yang saling tumpang tindih. Perppu 23/1959 mengatur lima kondisi sebagai bagian keadaan bahaya sebagaimana dijelaskan di atas, kemudian UU 24/2007 memisahkan bencana alam dan kerusuhan (bencana sosial) dari keadaan bahaya, selanjutnya UU 7/2012 kembali memisahkan konflik sosial (kerusuhan) dari bencana nasional dan dari kondisi keadaan bahaya, sehingga jika menggunakan asas lex specialis derogat legi generalis maka kondisi yang masih termasuk dalam keadaan bahaya hanya pemberontakan bersenjata dan perang, sehingga ketentuan tingkatan keadaan bahaya yang berlaku juga hanya tinggal keadaan darurat militer dan keadaan perang. Namun, yang tetap menjadi permasalahan adalah baik UU 24/2007 maupun UU 7/2012 tidak juga mencabut secara eksplisit kondisi bencana alam dan kerusuhan (konflik sosial) dari Perppu 23/1959. Justru yang semakin membuat ambigu adalah penjelasan UU 7/2012 menyatakan jika penetapan status konflik sosial dilakukan sebelum penetapan keadaan darurat sipil dideklarasikan. Hal ini praktis membuat konsep keadaan bahaya semakin ambigu.

Terdapat beberapa masalah terkait ambiguitasnya konsep keadaan bahaya di Indonesia. Pertama, Presiden menurut Pasal 12 UUD 1945 adalah subjek tunggal dalam melaksanakan keadaan bahaya yang diatur dengan undang-undang. Perppu 23/1959 adalah undang-undang yang dimaksud oleh Pasal 12 UUD 1945, karena hanya Perppu tersebut yang langsung merujuk pada Pasal 12 UUD 1945. Dalam praktiknya, UU 24/2007 memisahkan bencana alam dan bencana sosial (kerusuhan) untuk diatur

\footnotetext{
${ }^{26}$ Justin P. DePlato, American Presidential Power and the War on Terror, New York: Palgrave Macmillan, 2015, hlm. 36.

${ }^{27}$ Lihat, National Emergency Act 1976, Public Law 94-412—September. 14, 1976.
} 
Dialogia luridica: Jurnal Hukum Bisnis dan Investasi

Vol. 11 (1): $043-061$

tersendiri, dan memberikan kewenangan untuk menetapkan status darurat bencana dalam tiga tingkatan, meliputi status daruat bencana nasional, darurat bencana skala provinsi dan darurat bencana skala kabupaten/kota. Tiga status tersebut ditetap oleh Presiden, Gubernur dan Bupati/Walikota. Jika merujuk pada ketentuan Perppu 23/1959 semua keadaan tersebut harus ditetapkan dalam keadaan darurat sipil hanya oleh Presiden, namun jika menggunakan ketentuan UU 24/2007 Presiden tidak serta merta dapat menetapkan status darurat sipil, karena tidak ada terminologi darurat sipil dalam UU 24/2007, pun demikian dalam konflik sosial (kerusuhan atau perang saudara) jika menggunakan Perppu 23/1959 maka kerusuhan atau perang saudara harus ditetapkan status keadaan darurat sipil namun jika merujuk pada UU 7/2012 yang digunakan adalah status konflik sosial yang tingkatannya mutatis mutandis dengan UU 24/2007. Namun, terdapat penambahan ketentuan dalam UU 7/2012 di mana status konflik sosial dalam kasus kerusuhan atau perang saudara ditetapkan terlebih dahulu sebelum ditetapkannya keadaan darurat sipil. Intinya, UU 7/2012 menjadikan status konflik sosial sebagai dasar penerapan keadaan darurat sipil, sehingga dapat dipahami, keadaan darurat sipil dalam perkara kerusuhan/perang saudara tidak dapat ditetapkan sebagai keadaan darurat sipil sebelum adanya status konflik sosial.

Masalah kedua, pada Pasal 2 ayat 2 UU 31/1999 tentang pemberantasan tidak pidana korupsi memberlakukan pemberatan pidana berupa hukuman mati pagi koruptor yang melakukan korupsi dalam keadaan bahaya atau dalam keadaan bencana alam nasional. Masalahnya, keadaan bahaya yang mana dan merujuk pada undang-undang yang mana. Dan apakah pemberian hukuman mati tersebut dapat diterapkan jika Presiden belum menetapkan status keadaan bahaya. Dalam keadaan bencana nasional, tingkatan apa yang dijadikan dasar pemberian hukuman mati, apakah hanya pada tingkatan bencana nasional atau meliputi pula bencana skala provinsi atau kabupaten/kota. Hal ini yang kemudian menjadi ambigu karena banyaknya peraturan mengenai keadaan bahaya. Kemudian, terkait kewenangan pemerintah daerah dalam hal ini Gubernur, Bupati/Walikota dapat menerapkan status darurat bencana dan status konflik sosial, hal ini menjadi ambigu, karena pembagian tugas pemerintahan pusat dan daerah sudah ekplisit diatur dalam UU 23/2014 di mana bencana nasional dan konflik sosial berkaitan dengan pertahanan dan keamanan dan hal tersebut termasuk dalam kewenangan absolut pemerintah pusat, sehingga harusnya hanya Presiden yang dapat menetapkan status tersebut. Namun 
Dialogia luridica: Jurnal Hukum Bisnis dan Investasi

Vol. $11(1): 043-061$

ketentuan mengenai kewenangan tunggal presiden dalam menyatakan status konflik sosial dianulir oleh Mahkamah Konstitusi melalui putusan Nomor 8/PUU-XII/2014 yang menolak permohonan uji materi terhadap Pasal 16 dan Pasal 18 UU 7/2012 terkait kewenangan kepala daerah dalam penetapan status konflik sosial di daerah.

Masalah ketiga, lamanya status berbeda-beda dalam tiga peraturan tersebut. Pada Perppu 23/1959 bencana alam, kerusuhan, perang saudara dalam darurat sipil ditetapkan paling lama 6 bulan dan dapat diperpanjang selama 6 bulan, namun dalam UU 24/2007 tidak terdapat ketentuan mengenai batasan waktu penetapan status darurat bencana, Pasal 1 angka 19 UU 24/2007 hanya menyatakan status darurat bencana ditetapkan dalam waktu tertentu yang berarti tidak ada batasannya. Selanjutnya dalam UU 7/2012 lama penetapan status konflik sosial adalah 90 hari dan dapat diperpanjang selama 30 hari, sehingga dibatasi hanya 120 hari.

Masalah keempat, jika dirangkum status tingkatan dalam keadaan bahaya menjadi 9 jenis dengan lima kondisi: (1) keadaan darurat sipil; (2) keadaan darurat militer; (3) keadaan perang,; (4) status darurat bencana nasional; (5) status darurat bencana provinsi; (6) status darurat bencana kabupaten/kota; (7) status keadaan konflik nasional; (8) status keadaan konflik provinsi dan; (9) status keadaan konflik kabupaten/kota. Ambigunya, satu tingkatan yaitu status keadaan konflik menjadi syarat penetapan keadaan darurat sipil. Banyaknya tingkatan ini membuat sulitnya melihat konsep keadaan bahaya.

Masalah kelima, dalam Perppu 23/1959 Presiden tidak bertanggungjawab pada DPR sebagaimana dijelaskan dalam Penjelasan Umum angka 2 Perppu 23/1959 yang menyatakan:

“......Juga tidak diadakan pengawasan oleh Dewan Perwakilan Rakyat terhadap sesuatu pernyataan keadaan bahaya oleh Presiden, karena tidak sesuai dengan kedudukan Presiden menurut Undang-undang Dasar yang hanya bertanggung jawab terhadap Majelis Permusyawaratan Rakyat."

Ketentuan tersebut berbeda dengan UU 24/2007, di mana Presiden, Gubernur, Bupati/Walikota dalam menetapkan status darurat bencana hanya berdasarkan pertimbangan BNPB tanpa ada keterlibatan DPR atau DPRD, sedangkan dalam UU 7/2012, Presiden dalam menetapkan status keadaan konflik harus berkonsultasi dengan pimpinan DPR demikian pula Gubernur dan Bupati/Walikota harus berkonsultasi dengan pimpinan DPRD. 
Dialogia luridica: Jurnal Hukum Bisnis dan Investasi

Vol. 11 (1): $043-061$

\section{PENUTUP}

Keadaan bahaya yang terjadi di Indonesia terdiri dari beberapa jenis seperti perang, perang saudara, pemberontakan, konflik sosial dan bencana alam, dan jenis tersebut semuanya pernah terjadi di Indonesia. Peraturan yang dibuat untuk menaggulangi keadaan bahaya tersebut juga beragam, mulai dari Perpu 23/1959, UU 24/2007 dan UU 7/2012. Masalah kemudian lahir dalam tataran praktik di mana terdapat ketentuan yang tumpang tindih antar peraturan yang ada, sehingga berdampak pada penerapan aturan lain seperti UU 31/1999 dan UU 23/2014. Hal ini disebabkan oleh faktor konseptual keadaan bahaya yang belum dimiliki Indonesia, sehingga terdapat dua konsep yang coba disatukan, padahal dua konsep tersebut saling bertentangan. Pandangan mengenai asas neccesitas non habeat legem yang merupakan konsep kuno dengan pandangan asas ius fiction par excelence. Padahal jika dilihat dari format konstitusi, Indonesia lebih menganut asas ius fiction par excelence jika dilihat dari konstruksi Pasal 12 UUD 1945.

Pada era post modern, elaborasi keadaan bahaya dalam sistem hukum nasional merupakan suatu keharusan. Pandangan-pandangan yang menyatakan bahwa selama keadaan bahaya tidak memerlukan hukum (neccessitas non habeat legem) dapat dikatakan sudah tidak relevan dengan perkembangan zaman, terlebih lagi negara-negara modern sudah mengadopsi konsep negara hukum. Indonesia secara tegas menyatakan dalam Pasal 1 ayat 3 UUD 1945, bahwa Indonesia menganut negara hukum. Ambiguitas pengaturan keadaan bahaya menjadi faktor bahwa Indonesia belum memiliki konsep yang jelas bagaimana pengelolaan keadaan bahaya. Dalam beberapa peristiwa seperti pemberontakan di Papua oleh OPM seperti dibiarkan dan tanpa status apapun, kemudian dalam masalah bencana masih terus terjadi tarik ulur dalam menetapkan status bencana maupun dalam konflik sosial. Pada tragedi konflik juga demikian, tentu masih diingat bagaimana lambatnya negara menetapkan status darurat sipil dalam tragedi Sampit. Jika dianalisis, dalam tiap tragedi baik pemberontakan, bencana maupun konflik sosial, konfigurasi politik justru lebih dominan yang mengakibatkan tarik ulur dalam menentukan status suatu keadaan bahaya. Padahal, instrumen hukum sudah disiapkan dan hanya tinggal dieksekusi.

Harusnya, keadaan bahaya memiliki konsep tunggal yang mengatur secara holistik bagaimana penanganan keadaan bahaya. Konsep tersebut diberlakukan secara terpisah dari penyelenggaraan negara dalam keadaan normal, dan ketika suatu keadaan bahaya 
Dialogia luridica: Jurnal Hukum Bisnis dan Investasi

Vol. 11 (1): $043-061$

terjadi, Presiden sebagai kepala negara menyatakan status keadaan bahaya yang menjadi dasar pemberlakuan hukum tata negara darurat.

\section{DAFTAR PUSTAKA}

\section{Buku}

Carl Schmitt, Political Theology: Four Chapters on Theory of Sovereignty, Terjemahan George Schwab, Chicago: University of Chicago Press, 2005.

Chris Edelson, Emergency Presidential Power: From The Drafting of Constitution to the War on Terror, Wisconsin: The University of Wisconsin Press, 2013.

Chris Manning, Peter Van Dierman, Indonesia di Tengah Transisi: Aspek-Apek Sosial Reformasi Dan Krisis, Yogyakarta: LkiS, 2000.

Christopher Schroeder et al, Pesidential Power Stories, New York: Thomson Reuters/Foundation Press, 2009.

Georgio Agamben, The Omnibus Homo Sacer, Stanford: Standford University Press, 2017.

Giorgio Agamben, State of Exception, Chicago: The University of Chicago Press, 2005.

Harry Kawilarang, Aceh Dari Sultan Iskandar Muda Ke Helsinki. Banda Aceh: Bandar

Publishing, 2008.

Hasjim Djalal, Dini Sari Djalal, Seeking Lasting Peace in Aceh, Jakarta: Centre for Strategic and International Studies, 2006.

Herman Sihombing, Hukum Tata Negara Darurat, Jakarta: Djambatan, 1996.

Jimly Asshiddiqie, Hukum Tata Negara Darurat, Jakarta: Rajawali Press, 2007.

Justin P. DePlato, American Presidential Power and the War on Terror, New York: Palgrave Macmillan, 2015.

Panikos Panayi (ed), Weimar and Nazi Germany: Continuities and Discontinuities, New York: Routledge, 2014.

\section{Jurnal}

Anna Khakee, "Securing Democracy? A Comparative Analysis of Emergency Powers in Europe". "Geneva Centre for the Democratic Control of Armed Forces (DCAF)" Policy Paper No. 30, 2009. 
Dialogia luridica: Jurnal Hukum Bisnis dan Investasi

Vol. 11 (1): $043-061$

Bruce Ackerman, "The Emergency Constitution", Makalah dipresentasikan di The Cardozo Conference on Emergency Powers and Constitutions and the Yale Global Constitutuonalisme Seminar, 2004.

Claudio Grossman. "A Framework for the Examination of States of Emergency Under the American Convention on Human Rights." American University International Law Review Volume 1, No. 1, 1986.

Fitra Arsil, "Menggagas Pembatasan Pembentukan dan Materi Muatan Perppu: Studi Perbandingan Pengaturan dan Penggunaan perppu di Negara-Negara Presidensial”. Jurnal Hukum \& Pembangunan, Volume 48. No. 1 (2018).

Frank J. Williams, “A Popular Demand, and a Public Necessity": Lincoln and Civil Liberties. OAH Magazine of History, Volume 21, Issue 1, 2007.

Scott P. Sheeran, "Reconceptualizing States of Emergency under International Human Rights Law: Theory, Legal Doctrine, and Politics", Michigan Journal of International Law, Volume 34, Issue 3, 2013.

Stephen Humphreys, “Legalizing Lawlessness: On Giorgio Agamben's State of Exception", The European Journal of International Law Volume 17 No. 3, 2006.

\section{Artikel Media Masa}

Harian Kompas Digital “Hingga Minggu, Jumlah Korban Tewas Gempa dan Tsunami di Sulteng 1.763 Orang" 7 Oktober 2018. Diakses di www.nasional.kompas.com pada tanggal 9 September 2019.

Harian Kompas Digital, "Data Polisi, Korban Tewas akibat Kerusuhan di Wamena Berjumlah 31" pada 5 Oktober 2019. Diakses melalui laman www.regional.kompas.com pada 5 Oktober 2019.

Harian Tempo, “Jumlah Pengungsi Kerusuhan Wamena Lebih 10 Ribu Orang” pada tanggal 5 Oktober 2019. Diakses di www.nasional.tempo.com pada 5 Oktober 2019. 